\title{
OPEM
}

www.opem.org

Oriental Pharmacy and Experimental Medicine 2009 9(2), 142-148

DOI 10.3742/OPEM.2009.9.2.142

\section{Anxiolytic effect of leaf galls extracts of Pipernigrum Linn. in Swiss Albino mice}

\author{
Rajesh $\mathbf{R}^{1, *}$, Sathiyanarayanan $\mathbf{L}^{2}$, Arulmozhi $S^{3}$ and Ruby ${ }^{4}$ \\ ${ }^{1}$ Department of Pharmaceutical Chemistry, The Oxford College of Pharmacy, Bangalore-560 078, Karnataka, \\ India; ${ }^{2}$ Department of Pharmaceutical Chemistry; ${ }^{3}$ Department of Pharmacology Centre for advanced research \\ in Pharmaceutical Sciences, BVU's Poona College of Pharmacy, Erandwane, Pune-411 038. Maharastra, India; \\ ${ }^{4}$ Department of Pharmacology The Oxford College of pharmacy, Bangalore-560 078, Karnataka, India
}

Received for publication October 19, 2007; accepted January 05, 2008

\begin{abstract}
SUMMARY
Anxiety disorders are one of the serious problems which need proper therapy devoid of side effects of presently available medicines. The present study evaluates the anxiolytic and sedative activity of leaf galls of Piper nigrum Linn. in Swiss Albino mice. The pet. ether, chloroform, ethyl acetate and ethanol extracts of leaf galls of Piper nigrum Linn were obtained by continuous soxhlet extraction. The prepared extracts were found to be safe up to $2000 \mathrm{mg} / \mathrm{kg}$ body weight of mice in the acute toxicity study. Each extract was assessed for anxiolytic activity in Swiss Albino mice by elevated plus Maze, open field test, rota rod test and phenobarbitone induced sleeping time test. In the Elevated Plus Maze test, the pet.ether extract and chloroform extract at a dose of $50 \mathrm{mg} / \mathrm{kg}$ b.w. orally, significantly $(P<0.01)$ increased the number of entries and time spent in open arm comparable with standard diazepam at the dose of $10 \mathrm{mg} / \mathrm{kg}$. b.w. p.o. In the open field test, pet. ether extract $(50 \mathrm{mg} / \mathrm{kg}$ b.w. p.o.) showed significant increase $(P<0.01)$ in ambulation and activity in the center. Chloroform extract $(50 \mathrm{mg} / \mathrm{kg}$ b.w p.o.) was significant $(P<0.05)$ for both ambulation and center activity. Pet. ether extract $(50 \mathrm{mg} / \mathrm{kg}$ b.w. p.o) also showed significant activity $(P<0.01)$ in rota rod test. All the results are comparable with standard diazepam at the dose of $1 \mathrm{mg} / \mathrm{kg}$ b.w, p.o. Moreover all the extracts showed significant $(P<0.01)$ increase in the phenobarbitone induced sleeping time among which pet.ether showed more prominent activity (36\%) comparable with control. The results revealed that, the active pet.ether extract and chloroform extract of leaf galls of Piper nigrum Linn is worthwhile to develop the bioactive principle for anxiolytic activity.
\end{abstract}

Key words: Anxiolytic; Piper nigrum; Leaf galls; Elevated plus maze

\section{INTRODUCTION}

Anxiety disorders in a modern society have a relative high prevalence and command considerable

\footnotetext{
*Correspondence: Rajesh R, Department of Pharmaceutical Chemistry, The Oxford College of Pharmacy, Bangalore-560 078, Karnataka, India. Tel: +08022452500; E-mail: pharmsathiya@gmail.com
}

financial resources. Benzodiazepines are the most widely prescribed class of psychoactive drugs in current therapeutic use, despite the important unwanted side-effects that they produce such as sedation, myorelaxation, ataxia, amnesia, ethanol and barbiturate potentiation and tolerance (File, 1987). Therefore the development of new medications possessing anxiolytic effect without the complication 
of benzodiazepines would be of great importance in the treatment of anxiety related disorders. Medicinal plants are a good source to find new remedies for these disorders. Worldwide researchers are emphasizing herbal-based therapy for the treatment of such disorders. It is well known that some plant extracts and isolated constituents from plants possess anxiolytic and sedative activities (Peng et al., 2000; Cha et al., 2004).

Piper nigrum Linn belongs to the family Piperaceae (Trease and Evans, 1985), a stout glabrous climber is found in South Western parts of India. This plant finds extensive use in the Ayurvedic system of medicine (Chopra et al., 1958). This plant has been used as a stimulant, carminative, antitubercular (Chopra et al., 1956, 1958), oxytocic (Banerjee and Dandia, 1967), and insecticide (Chandhoke et al., 1968). A number of piperidine and pyrolidine alkamide present in piper species are known to posses a variety of biological properties like CNS stimulant, analgesic, antipyretic, and antifeedant activities (Miyakado et al., 1979). Galls are pathologically developed cells, tissues, and organs of plants, which have risen mostly under the influence of parasitic organism. Recently we have demonstrated the anti-inflammatory activity of the leafgalls of Piper nigrum Linn in Albino wistar rats (Rajesh et al., 2007). Literature survey revealed that tannins and flavonoids possess activity against many CNS disorders (Takahash et al., 1986, Aguirre-Hernández et al., 2007). Phytochemical studies revealed the presence of tannins and flavonoids in the leafcgalls of Piper nigrum Linn. (Rajesh et al., 2007). Although many medicinal properties have been attributed to the extracts of this plant, there is a scarcity of scientific data in leaf galls of pipernigrum Linn and there is no substantiation about the anxiolytic and sedative activity of the leaf galls extracts of this plant. On this basis, the present study is deliberated to investigate the anxiolytic and sedative effect of various extracts of leaf galls of Piper nigrum Linn in mice.

\section{MATERIALS AND METHODS}

Fresh leaf galls of Piper nigrum Linn. were collected from the local areas of Kanyakumari district, Tamilnadu state in the month of November and were identified by Prof. Pamela Mohandoss, Dept. of Botany, Lady Doak College, Madurai. A voucher specimen (LPN-01) has been deposited at the departmental herbarium, K.M.College of Pharmacy, Madurai. Diazepam injection (calmpose, Ranbaxy, India) and phenobarbitone sodium were purchased commercially. All the reagents used were of analytical grade (Merck) purchased from local stockist, Tamilnadu, India.

Healthy, female Albino mice weighing between $20-25 \mathrm{~g}$, acclimatized to our laboratory condition under standard animal house conditions, were used. CPCSEA guidelines were adhered to during the maintenance and experiment. Experiment protocol was submitted to Institutional Animal Ethics Committee and approval was taken.

\section{Preparation of extract}

The leaf galls $(500 \mathrm{~g})$ were shade dried and reduced to coarse powder, subjected to continuous hot extraction with petroleum ether, chloroform, ethyl acetate and $90 \%$ ethanol in a Soxhlet extractor for $72 \mathrm{~h}$. The obtained extracts were filtered and evaporated to dryness at $40^{\circ} \mathrm{C}$ under reduced pressure in a rota evaporator. The yields of petroleum ether, chloroform, ethyl acetate and ethanol extracts were found to be $10 \mathrm{~g}, 14 \mathrm{~g}, 15 \mathrm{~g}$ and $17 \mathrm{~g}$, respectively. All the extracts were kept in a dessicator till experimentation. The extracts were suspended in $0.5 \% \mathrm{w} / \mathrm{v}$ of sodium lauryl sulphate (SLS) for the pharmacological studies.

\section{Preliminary phytochemical studies}

The preliminary qualitative phytochemical screening of the extracts was performed to identify the presence of possible phytoconstituents (Clarke, 1975). 


\section{Acute toxicity studies}

Acute toxicity study was carried out for all the extracts following OECD guidelines (OECD, 2001). Overnight fasted, healthy mice $(n=3)$ were administered orally the respective extracts in the dose of $2000 \mathrm{mg} / \mathrm{kg}$ body weight and observed continuously for $4 \mathrm{~h}$ and $24 \mathrm{~h}$ for any abnormality and mortality.

\section{Drug treatment}

The animals were divided into six groups each of six animals. Group III, IV, V and VI were administered with pet. Ether, chloroform, ethyl acetate and ethanol extracts respectively at the dose of $50 \mathrm{mg} / \mathrm{kg}$ b.w orally. Group II received standard drug diazepam $(1 \mathrm{mg} / \mathrm{kg}$. b.w $)$ and vehicle $10 \mathrm{ml} / \mathrm{kg}$ b.w. Group I act as control received vehicle $10 \mathrm{ml} / \mathrm{kg}$ b.w. alone. The above drug treatment was followed for elevated plus maze test, open field behaviour and rota rod test.

\section{Assessment of CNS activity: anxiolytic activity on} elevated plus maze (Gorbett et al., 1991)

The elevated plus maze consists of two open arms $(15 \times 5 \mathrm{~cm})$ and two closed arms $(15 \times 5 \times 12 \mathrm{~cm})$ with the open air perpendicular to the closed one. The maze was made of clear acrylic and was located $29 \mathrm{~cm}$ above a black floor. After $30 \mathrm{~min}$ of the drug treatment, the animals were individually placed at the center of the plus maze and observed for $5 \mathrm{~min}$. The time in seconds, spent by the animals in the open arm, closed arm and number of entries in both the arms were noted. Anxiolytic compounds reduce the animal's natural aversion to the open arms and promoted exploration. Therefore, increased number of entries and time spent in the open arm was considered to reflect an anxiolytic effect, in comparison with the control group. The results are tabulated in Table 1 .

\section{Open field test}

The open field test was carried out by the method suggested by Ambavade et al (Ambavade et al., 2006). The dark grey floor subdivided into 16 equal parts in a wooden box was used. After $45 \mathrm{~min}$ of the treatment with the extracts of Piper nigrum Linn at the dose of $50 \mathrm{mg} / \mathrm{kg}$ b.w, the animals were individually placed in the corner square of the open field. Spontaneous ambulation (number of segments crossed at periphery), activity in the centre (number of central squares crossed) and total locomotion (total number of squares crossed), were observed for $5 \mathrm{~min}$. The results are tabulated in Table 2. Rota-Rod Test: (Muscle relaxant activity) (Dunham and Miya et al., 1957).

Untreated mice were placed on a horizontal wooden rod (32 $\mathrm{mm}$ diameter), rotating at a speed of $5 \mathrm{rpm}$. The animals remaining on the rod for 3 min or more in successive trial were selected for the study. After drug treatment, each group was placed on the rod at intervals of 30, 60, 90 and 150 min after treatment. The time taken for the mice to fall from the rotating rod was noted. The results are tabulated in Table 2. Effect of Phenobarbitone

Table 1. Table showing results of Elevated Plus Maze test

\begin{tabular}{lccc}
\hline Treatment & $\begin{array}{c}\text { Time spent in } \\
\text { Open Arm }\end{array}$ & $\begin{array}{c}\text { No. of entries in } \\
\text { open arm }\end{array}$ & $\begin{array}{c}\text { No. of entries in } \\
\text { Closed arm }\end{array}$ \\
\hline Control & $98.67 \pm 5.287$ & $2.833 \pm 0.3073$ & $3.5 \pm 0.2236$ \\
Petroleum Ether $(50 \mathrm{mg} / \mathrm{Kg})$ & $176.84 \pm 3.547^{* *}$ & $7 \pm 0.2582^{* *}$ & $2.83 \pm 0.1667$ \\
Chloroform $(50 \mathrm{mg} / \mathrm{Kg})$ & $148 \pm 1.255^{* *}$ & $6.33 \pm 0.21^{* *}$ & $2.83 \pm 0.3073$ \\
Ethyl Acetate $(50 \mathrm{mg} / \mathrm{Kg})$ & $110.67 \pm 1.235$ & $3.85 \pm 0.2108^{*}$ & $3.166 \pm 0.307$ \\
Ethanol $(50 \mathrm{mg} / \mathrm{Kg})$ & $101.67 \pm 2.365$ & $3.96 \pm 0.212^{*}$ & $3.83 \pm 0.307$ \\
Diazepam $(1 \mathrm{mg} / \mathrm{kg}$, i.p.) & $165.72 \pm 3.548^{* *}$ & $8 \pm 0.2582^{* *}$ & $4.56 \pm 0.2236^{*}$ \\
\hline
\end{tabular}

Values are mean \pm S.E.M, $(n=6) .{ }^{*} P<0.05,{ }^{* *} P<0.01$ compared to control group (One-way ANOVA followed by Dunnet's Multiple Comparison test). 
Table 2. Table showing results of Open Field Test

\begin{tabular}{lccc}
\hline & \multicolumn{3}{c}{ Open Field Behaviour } \\
\cline { 2 - 4 } Treatment & $\begin{array}{c}\text { Ambulations (Number of } \\
\text { squares crossed at } \\
\text { periphery) }\end{array}$ & $\begin{array}{c}\text { Activity at centre } \\
\text { (number of central } \\
\text { squares crossed) }\end{array}$ & $\begin{array}{c}\text { Total locomotion } \\
\text { (total number of } \\
\text { squares traveled) }\end{array}$ \\
\hline Control & $77.66 \pm 3.59$ & $3 \pm 0.2582$ & $62.33 \pm 0.2682$ \\
Petroleum Ether $(50 \mathrm{mg} / \mathrm{Kg})$ & $98 \pm 1.528^{* *}$ & $11.67 \pm 0.5^{* *}$ & $92.16 \pm 0.2236^{* *}$ \\
Chloroform $(50 \mathrm{mg} / \mathrm{Kg})$ & $89 \pm 1.438^{*}$ & $8.66 \pm 0.426^{*}$ & $72.26 \pm 0.2108^{* *}$ \\
Ethyl Acetate $(50 \mathrm{mg} / \mathrm{Kg})$ & $79 \pm 2.95$ & $8 \pm 0.4472^{*}$ & $70.28 \pm 0.4492^{* *}$ \\
Ethanol $(50 \mathrm{mg} / \mathrm{Kg})$ & $72.66 \pm 2.108$ & $7 \pm 0.4472$ & $73.5 \pm 0.3416^{* *}$ \\
Diazepam $^{+}(1 \mathrm{mg} / \mathrm{kg}$, i.p.) & $100.16 \pm 2.286^{* *}$ & $13.166 \pm 0.4014^{* *}$ & $112.5 \pm 0.5^{* *}$ \\
\hline
\end{tabular}

$\mathrm{V}$ alues are mean $\pm \mathrm{SEM},(\mathrm{n}=6)$.

${ }^{*} P<0.05,{ }^{* *} P<0.01$ compared to control group (One-way ANOVA followed by Dunnet's Multiple Comparison test).

sodium induced sleeping time (Turner, 1965).

This test was conducted as suggested by Turner. Healthy albino mice weighing between $20-25 \mathrm{~g}$ were fasted for $24 \mathrm{~h}$ before the experiment and were divided into 5 groups of 6 animals each. The pet. ether, chloroform, ethyl acetate and ethanol extracts were administered to group II, III, IV, and $\mathrm{V}$ at a doe of $50 \mathrm{mg} / \mathrm{kg} \mathrm{b.w}$, and control group I received vehicle $(10 \mathrm{ml} / \mathrm{kg})$ alone. $30 \mathrm{~min}$ after administration, each animal was administered with phenobarbitone sodium ( $40 \mathrm{mg} / \mathrm{kg}$ b.w. p.o). The sleeping time was noted by recording the time interval between loss and return of righting reflex. The results are tabulated and shown in Table 3.

\section{Statistical analysis}

All the results were analyzed for statistical significance

Table 3. Table showing results of Rota rod test

\begin{tabular}{lc}
\hline Treatment & $\begin{array}{c}\text { Time Spent on } \\
\text { Rota rod (s) }\end{array}$ \\
\hline Control & $19.5 \pm 1.38$ \\
Petroleum Ether $(50 \mathrm{mg} / \mathrm{Kg})$ & $14.4 \pm 0.98^{* *}$ \\
Chloroform $(50 \mathrm{mg} / \mathrm{Kg})$ & $15.7 \pm 0.49$ \\
Ethyl Acetate $(50 \mathrm{mg} / \mathrm{Kg})$ & $15.2 \pm 1.3^{*}$ \\
Ethanol $(50 \mathrm{mg} / \mathrm{Kg})$ & $17.2 \pm 1.2$ \\
Diazepam $^{+}(1 \mathrm{mg} / \mathrm{kg}$, i.p. $)$ & $10.25 \pm 0.56^{* *}$ \\
\hline
\end{tabular}

Values are mean \pm S.E.M. $(n=6) .{ }^{*} P<0.05,{ }^{* *} P<0.01$ compared to control group (One-way ANOVA followed by Dunnet's Multiple Comparison test). by performing one-way ANOVA followed by Dunnet's multiple comparison test. $P<0.05$ implies significance.

\section{RESULTS}

Neither mortality nor any visible changes were observed during the acute toxicity studies. Hence the extracts in the dose up to $2000 \mathrm{mg} / \mathrm{kg}$ body weight were found to be safe in laboratory animals.

The preliminary qualitative phytochemical study showed the presence of triterpenoids, flavonoids and tannins in all the extracts (Rajesh et al., 2007).

In the elevated plus maze, the pet.ether extract and chloroform extract at a dose of $50 \mathrm{mg} / \mathrm{kg}$ significantly $(P<0.01)$ increased the number of entries and time spent in the open arm. The standard Diazepam at a dose of $1 \mathrm{mg} / \mathrm{kg}$ significantly $(P<$ 0.01 ) increased the number of entries and time spent in the open arm (Table 1).

In the open field test, pet. ether extract showed a significant increase $(P<0.01)$ in ambulation and activity in the center. Chloroform extract was significant $(P<0.05)$ for both ambulation and center activity. Other extracts are not significant except ethyl acetate extract, which was significant $(P<0.05)$ only in the central activity. All extracts showed significant $(P<0.01)$ total locomotion.

In rota rod test, Pet. ether extract and ethyl 
Table 4. Table showing phenobarbitone induced sleeping time of Leaf galls of Piper nigrum Linn

\begin{tabular}{lccc}
\hline Treatment & Phenobarbitone sodium & Sleeping time $(\mathrm{min})$ & Increase in sleeping time \\
\hline Control & $40 \mathrm{mg} / \mathrm{kg}$ & $44.8 \pm 1.934$ & - \\
Petroleum Ether $(50 \mathrm{mg} / \mathrm{kg})$ & $40 \mathrm{mg} / \mathrm{kg}$ & $70.8 \pm 1.772^{* *}$ & $36.72 \%$ \\
Chloroform $(50 \mathrm{mg} / \mathrm{kg})$ & $40 \mathrm{mg} / \mathrm{kg}$ & $62.8 \pm 2.288^{* *}$ & $28.66 \%$ \\
Ethyl Acetate $(50 \mathrm{mg} / \mathrm{kg})$ & $40 \mathrm{mg} / \mathrm{kg}$ & $63.2 \pm 3.277^{* *}$ & $29.72 \%$ \\
Ethanol $(50 \mathrm{mg} / \mathrm{kg})$ & $40 \mathrm{mg} / \mathrm{kg}$ & $64.6 \pm 2.654^{* *}$ & $30.64 \%$ \\
\hline
\end{tabular}

ANOVA followed by Dunnet's $t$ test . ${ }^{*} P<0.01$ compared to control group. Values are expressed as mean \pm S.E.M of six values.

acetate extract showed significant motor dis coordination of $(P<0.01)$ and $(P<0.05)$ respectively, where as other extracts were not significant. The reference drug Diazepam significantly $(P<0.01)$ showed motor dis co-ordination (Table 2).

The phenobarbitone induced sleeping activity showed that all the extracts produced a significant increase in the hypnotic effect. The duration of sleeping time expressed as percentage effect is maximum obtained by pet.ether extract (36\%) followed by ethanol, ethyl acetate and chloroform extracts respectively (Table 3 ).

\section{DISCUSSION}

Anxiolytic compounds reduce the animal's natural aversion to the open arms and promoted exploration in the elevated plus maze test. Therefore, increased time spent in the open arms was considered to reflect an anxiolytic effect, in comparison with the control group. The decrease in the aversion to the open arm in the Elevated plus Maze test is the result of an anxiolytic effect, expressed by the increased time spent in the open arm. In the present study, Pet. ether and chloroform extracts significantly increased both the number of entries and time spent in open arm suggested that behaviour alterations induced by these extracts were consistent with anxiolytic activity. The number of entries in closed arm was reduced. Eventhough the reduction was not statistically significant, it was not increased indicating that the locomotor activity did not increased by the extracts treated group compared to control group. The standard drug diazepam increased the number of entries so that increased the locomotor activity as expected.

In the open field test, rodents show thigmotaxic behaviour identified by spontaneous reference to the periphery of the apparatus and reduced ambulation. (Bhattacharya and Satyan, 1997) The inhibition or marked decrease in the exploratory behaviour usually, is decreased by anxiolytic agents. In the present study the pet.ether extract showed prominent effect on ambulation than chloroform extract. All extracts other than ethanolic extract were significant in the central activity in which pet.ether extract was more prominent. The significant increase $(P<0.01)$ in locomotion was observed by all the extracts.

The increased ambulation, and higher central activity in the OFT further supports the results of Elevated plus maze for the anxiolytic activity. The rota rod test, which can explain the muscle relaxant activity of animals, showed similar type of activity like Diazepam. Diazepam significantly reduces the motor coordination. Diazepam is a very well known anxiolytic benzodiazepine (BDZ) which produces important sedative effects (Shader and Greenblatt, 1993). In phenobarbitone induced sleeping time, all the extracts significantly enhanced the percentage effect in which Pet.ether is more prominent. Such an effect might arise for a CNS depressant action (Fastier et al., 1957) or tranquilizing action (Mukharjee et al., 1996). It has been reported that an inhibition in hepatic enzymatic metabolism may prolong the sleeping time induced by barbiturate (Gyamfi et al., 
2000) and also the activation of the inhibitory GABAergic system is involoved in the effects of phenobarbital on the CNS (Steinbach and Akk, 2001). In the present study, the Pet. ether extract at the same dose exhibiting anxiolytic activity, motor in coordination and potentiating phenobarbitone sleeping time. Eventhough, from the rota rod test and phenobarbitone induced sleeping time, there may be a possibility of sedative effect for the extract, the increased ambulation and locomotion in the OFT is contradicted for the sedative effect. The total number of crossings in the field is an index of non specific locomotion activity (Schmitt and Hiemke 1998). But moderate dose of benzodiazepines are known to decrease activity in rats and to increase it in mice (Prut and Belzung, 2003). Similar activity was found in present study where diazepam $1 \mathrm{mg} / \mathrm{kg}$ increased the total locomotion. Similarly the pet.ether and chloroform extracts showed activities which can be well correlated with diazepam. Also previous studies showed that plant extracts which possess anxiolytic effect at low doses exhibiting sedative effect at high doses (Ambavade et al., 2006). However at this position it is difficult to conclude for the sedative activity of the extract. Further dose dependant studies with higher doses and locomotor activity studies are required to confirm the sedative property, which are in process.

All the above observations are quite sufficient to conclude that the leafgalls of pipernigrum Linn possessing anxiolytic activity which we are reporting for the first time. The results are well agreed with the earlier report by Aguirre Hernandez et al (Aguirre-Hernández et al., 2007) in the case of evaluation of Tilia americana L. var. mexicana. Earlier studies revealed that tannins and flavonoids have been shown to possess activity against many CNS disorders. As the phytochemical studies shows the presence of tannins and flavonoids and the anxiolytic activity of any phytoconstituent of leaf galls of this plant is still remained unexplored, it is worthwhile to isolate the bioactive principle which is responsible for the activity and its possible mechanism to be studied thoroughly.

To summaries the pet.ether and chloroform extract of leaf galls of pipernigrum Linn at a dose of $50 \mathrm{mg} / \mathrm{kg}$ possesses more anxiolytic activity than the ethyl acetate and ethanol extracts. Diazepam at a dose of $1 \mathrm{mg} / \mathrm{kg}$ showed more activity than all extracts. The above results suggest that the leafgalls of this plant can be used as an alternative for the currently available anxiolytic drugs.

\section{ACKNOWLEDGEMENTS}

The authors are grateful to the Director, principal and management of KM College of pharmacy, Madurai and The Oxford College of pharmacy, Bangalore for their technical support and encouragement to carryout this work.

\section{REFERENCES}

Aguirre-Hernández E, Martínez AL, GonzálezTrujano ME, Moreno J, Vibrans H, Soto-Hernández M. (2007) Pharmacological evaluation of the anxiolytic and sedative effects of Tilia americana L. var. mexicana in mice. J. Ethnopharmacol. 109, 140-145.

Ambavade SD, Mhetre NA, Tate VD and Bodhankar SL. (2006) Pharmacological evaluation of the extracts of sphaeranthus indicus flowers on anxiolytic activit inmice. Indian J. Pharmacol. 38, 254-259.

Banerjee SP, Dandia PC. (1967) Indian J. Physiol. Pharmacol. 2, 139-146.

Bhattacharya SK, Satyan KS. (1997) Experimental methods for evaluation of psychotropic agents in rodents: I-Antianxiety agents. Indian J. Exp. Biol. 35, 565-575.

Cha HY, Seo JJ, Park JH, Choi KJ, Hong JT , Oh JK. (2004) Anxiolytic effects of total saponin fraction from Ginseng Radix rubra on the elevated plusmaze model in mice. Ginseng Res. 28, 132-135.

Chandhoke N, Ray Ghatak BJ. (1968) Indian J. Exp. Biol. 6, 33-35.

Chopra RN, Chopra IC, Handa KL, Kapur LD. (1958) Chopra's Indigenous drugs of India, p. 224-226, UN Dhar \& Sons Pvt. Ltd., Calcutta.

Chopra RN, Nayar SL, Chopra IC. (1956) Glossary of 
Indian medicinal plants, p. 194 CSIR: New Delhi. Clarke EGC. (1975) Isolation $\mathcal{E}$ Identification of drugs, $2^{\text {nd }}$ edition, Pharmaceutical Press: London; p. 905.

Dunham NM, Miya TS. (1957) A note on simple apparatus for detecting Neurological deficit in rats and mice. J. Am. Pharm. 46, 208-209.

Fastier FN, Spended RN, Hendriek W. (1957) Prolongation of chloral hydrae sleeping time by 5HT and by certain other drugs. Br. J. Pharmacol. 12, 251-259.

File SE. (1987), The contribution of behavioral studies to the neuropharmacology of anxiety. Neuropharmacology 26, 877-886.

Gorbett R, Fielding ST, Cornfeldt M, Dunn RW. (1991) GABA mimetic agents display anxiolytic-like effects in the social interaction and elevated plus maze procedures. Psychoharmacology 104, 312-316.

Gyamfi MA, Hokama N, Oppong Boachie K, Aniya Y. (2000) Inhibitory effects of the medicinal herb, thonningia sanguinea, on liver drug metabolizing enzymes of rats. Human Exp. Toxicol. 19, 623-631.

Miyakado M, Nakayam I, Yoshioka H, Nakatani N. (1979) The piperaceae amides, Structure of pipercide, a new insecticidal amide from pipernigrum L. Agric. Biol. Chem. 43, 1609-1611.

Mukharjee PK Saha K. Balasubramanum R, Pal M, Saha BP. (1996) Studies of Psychopharmacological effects of Nelumbo nucifera Gaertn, Rhizome extract. J. Ethnopharmacol. 54, 63-67.
OECD Environment, health and safety publications, Paris 2001 (www.oecd.org/ehs).

Peng WH, Hseeih MT, Lee YS, Lin YC, Liao J.(2000) Anxiolytic effect of seed of Ziziphus jujuba in mouse models of anxiety. J. Ethnopharmacol. 72, 435-441.

Prut L, Belzung C. (2003). The open field as a paradigm to measure the effects of drugs on anxiety-like behaviors: a review. Eur. J. Pharmacol. 463, 3-33.

Rajesh R, Sathiyanarayanan L, Arulmozhi S, Jubie S, Sarfaraz Md. Effect of leaf galls of Piper nigrum Linn. against carageenan induced inflammation in Albino rats. J. Nat. Rem. (in press).

Schmitt U, Hiemke C. (1998) Strain differenced is open field and elevated plus maze behavior of rats without and with pretest handling. Pharmacol. Biochem. Behav. 59, 807-811.

Shader RI, Greenblatt DJ. (1993) Use of benzodiazepines in anxiety disorders, New Engl. J. Med. 328, 13981405.

Steinbach JH, Akk G. (2001). Modulation of GABA receptor channel gating by entobarbital. J. Physiol. 537, 715-733.

Takahash RN, delima TC, Muraio GS. (1986) Pharmacological actions of tannic acid: II Evaluation of CNS activity in animals. Planta Med. 4, 272-275.

Trease GE, Evans WL. (1985) Text book of Pharmacognosy, pp. 378-380, Elsevier Publications: London.

Turner RA. (1965) Screening method in pharmacology. p72 Academic Press, New York. 